\title{
Pengaruh Penambahan Bacillus sp. Terhadap Kelulushidupan Pasca Larva Udang Vannamei (Litopenaeus vannamei) yang Terinfeksi Vibriosis.
}

\author{
Yufinta Cahya Permantia, Pande Gde Sasmita Julyantoro ${ }^{a}$, Made Ayu Pratiwi ${ }^{a}$ \\ a Program Studi Manajemen Sumberdaya Perairan/Fakultas Kelautan dan Perikanan, Universitas Udayana, Bukit Jimbaran, Badung, Bali- \\ Indonesia
}

*Penulis koresponden. Tel.: +628762225893

Alamat e-mail: cahyayufintapermanti@gmail.com

Diterima (received) 11 Juni 2018; disetujui (accepted) 15 Agustus 2018

\begin{abstract}
This study was aimed to investigated the effect of Bacillus sp. on the survival of Litopenaeus vannamei post larvae when challenged with pathogenic Vibrio harveyi. The experimental research was done by using completely randomized design with 4 treatments and 3 replications. Treatment A (control) was done without addition of bacteria, treatment B with the addition of $V$. harveyi $10^{6} \mathrm{CFU} / \mathrm{ml}$, treatment $\mathrm{C}$ with addition of Bacillus sp. $10^{5} \mathrm{CFU} / \mathrm{ml}$, and treatment D with the addition of $V$. harveyi $10^{6} \mathrm{CFU} / \mathrm{ml}$ and Bacillus sp. $10^{5} \mathrm{CFU} / \mathrm{ml}$ to the culture water. Bacterial abundance was calculated at the end of the research in TCBS and LB agar media to know their persistence in the culture water. All of data were tested statistically by using One Way Anova followed with Tukey Test. The results showed that addition of Bacillus sp. in shrimp postlarvae infected by vibriosis (treatment D) can increase shrimp survival about $(82.6 \pm 2.3) \%$ that significantly different $(\mathrm{p}<0,05)$ compared to the culture without addition of Bacillus sp. (treatment B) which has only $(49.3 \pm 4.6) \%$. Meanwhile, the highest survival was still obtained in treatment A $(85.3 \pm 4.6) \%$. Interestingly, the addition of Bacillus sp. in the unchallenged post larvae (treatment C) resulted in the lower shrimp survival (69.3 \pm $4.6 \%$ compared to the control (treatment A). This study indicated that the addition of Bacillus sp can increase the survival rate of Vannamei shrimp postlarvae infected byvibriosis disease
\end{abstract}

Keywords: AHL-Degrader;Quorum sensing; Vibrio

\begin{abstract}
Abstrak
Penelitian ini bertujuan untuk mengetahui pengaruh penambahan bakteri Bacillus sp. terhadap tingkat kelulushidupan pasca larva udang putih Litopenaeus vannamei yang diuji tantang dengan bakteri patogen Vibrio harveyi.Penelitian dilakukan secara eksperimental menggunakan Rancangan AcakLengkap (RAL) dengan 4 perlakuan dan 3 kali ulangan. Perlakuan A (kontrol) yaitu tanpa penambahan bakteri, perlakuan B yaitu dengan penambahan bakteri $V$. harveyi $10^{6} \mathrm{CFU} / \mathrm{ml}$, perlakuan $\mathrm{C}$ ditambahkan bakteri Bacillus sp. $10^{5} \mathrm{CFU} / \mathrm{ml}$, dan perlakuan D dengan penambahan $V$. harveyi $10^{6} \mathrm{CFU} / \mathrm{ml}$ dan bakteri Bacillus sp. $10^{5} \mathrm{CFU} / \mathrm{ml}$ pada air kultur. Kelimpahan bakteri dihitung pada akhir penelitian pada media TCBS dan LB Agar untuk mengetahui persistensi bakteri pada air kultur. Seluruh data diuji secara statistik menggunakan One Way Anova kemudian dilanjutkan dengan Uji Tukey. Hasil penelitian menunjukkan bahwa penambahan Bacillus sp. pada udang yang terinfeksi vibriosis (perlakuan D) mampu menghasilkan persentase kelulushidupan sebesar $(82.6 \pm 2.3) \%$ dan berbeda nyata $(\mathrm{p}<0,05)$ dibandingkan dengan tanpa penambahan Bacillus sp. (perlakuan B) yang hanya memiliki persentase kelulushidupan sebesar $(49.3 \pm 4.6) \%$. Sedangkan persentase kelulushidupan tertinggi masih didapatkan pada perlakuan A $(85,3 \pm 4,6) \%$. Menariknya, penambahan Bacillus sp. pada udang yang tidak terinfeksi vibriosis (perlakuan C) ternyata menghasilkan persentase kelulushidupan yang lebih rendah $(69.3 \pm 4.6) \%$ daripada kontrol. Hal ini mengindikasikan bahwa penambahan bakteri Bacillus sp. mampu meningkatkan kelulushidupan pasca larva UdangVannamei yang terinfeksi vibriosis.
\end{abstract}

Kata Kunci: AHL-Degrader; Quorum sensing; Vibrio 


\section{Pendahuluan}

Udang Vannamei (L. vannamei) merupakan salah satu jenis udang introduksi yang banyak diminati untuk dibudidayakan, karena memiliki beberapa keunggulan yaitu responsif terhadap pakan yang diberikan, dapat bertahan pada kondisi yang kurang baik dan lebih tahan terhadap serangan penyakit. Namun, dalam produksi budidaya Udang Vannamei mengalami beberapa hambatan. Salah satu penghambat utama produksi budidaya Udang Vannamei adalah terjadinya serangan penyakit terutama yang disebabkan oleh bakteri. Salah satu serangan penyakit bakteri yang sering menyerang Udang Vannamei adalah penyakit vibriosis (Maryani et al., 2002).

Vibriosis merupakan penyakit yang disebabkan oleh bakteri Vibrio sp. Jenis bakteri vibrio yang telah diketahui sebagai penyebab utama vibriosis adalah jenis $V$. harveyi (Le Groumellec et al., 1996). $V$. harveyi merupakan bakteri laut gram negatif berbentuk batang dan bersifat motil yang dapat menjadi bakteri patogen bagi ikan dan invertebrata laut, salah satunya pada Udang Vannamei.

$V$. harveyi tumbuh secara optimal pada suhu $30^{\circ} \mathrm{C}$, salinitas antara 20-30 ppt dengan $\mathrm{pH} 7,0$ dan bersifat anaerobik fakultatif, yaitu dapat hidup dengan oksigen atau tanpa adanya oksigen (Holt and Krieg, 1984). Sejauh ini $V$. harveyi telah diketahui dapat berkomunikasi antar individu satu spesies dengan mekanisme quorum sensing (Fuqua dan Greenberg, 2002). Quorum sensing (QS) merupakan mekanisme komunikasi di antara sel bakteri secara interseluler, tergantung pada kepadatan jumlah sel yang berperan penting dalam regulasi ekspresi gen untuk mengontrol perubahan ekspresi gen sebagai respon terhadap fluktuasi kepadatan populasi. Vibrio harveyi memiliki 3 jenis molekul sinyal yang disebut autoinduser yaitu Harveyi autoinducer 1 (HAI-1) yang merupakan kelompok Acyl homoserine lactone (AHL); Harveyi autoinducer 2 (AI-2), dan Cholerae autoinducer 1 (CAI-1) (Henke and Basler, 2004).

Strategi pengendalian vibriosis pada udang pada umumnya dilakukan menggunakan antibiotik. Namun, penggunaan antibiotik secara terus menerus akan menimbulkan sifat resistensi pada bakteri (Nakayama et al., 2005). Salah satu alternatif terkini yang dapat ditawarkan untuk mengendalikan virulensi bakteri patogen adalah dengan memanfaatkan kemampuan bakteri dalam mendegradasi sinyal QS secara enzimatik. Salah satu jenis bakteri yang mampu mendegradasi sinyal QS adalah Bacillus sp.

Bacillus sp. mampu menghasilkan enzim pendegradasi salah satu molekul sinyal QS kelompok AHL yaitu enzimAHL-laktonase (Molina et al., 2003). Degradasi A HL oleh enzim ini akan menyebabkan mekanisme QS terhambat dan gen-gen patogenetik tidak diekspresikan oleh bakteri patogen (Dong et al., 2002). Penelitian ini bertujuan untuk mengetahui pengaruh penambahan Bacillus sp. terhadap kelulushidupan dan pertumbuhan pasca larva udang putih Litopenaeus vannamei yang terinfeksi vibriosis melalui uji tantang dengan $V$. harveyi.

\section{Metode Penelitian}

\subsection{Waktu dan Tempat}

Penelitian ini dilakukan di Laboratorium Perikanan Fakultas Kelautan dan Perikanan Universitas Udayana pada bulan April hingga bulan Mei 2018.

\subsection{Alat dan Bahan}

Alat dan bahan yang digunakan dalam penelitian ini antara lain cawan petri dan tabung reaksi untuk wadah kultur bakteri, erlenmayer, mikropipet (Scigolex, USA), akuarium $40 \times 25 \times 25$ $\mathrm{cm}$ untuk waterbath yang dilengkapi heater dan aerator, toples plastik volume $500 \mathrm{ml}$ sebagai wadah kultur pasca larva udang. Sedangkan bahan yang digunakan dalam penelitian meliputi isolat V. harveyi, isolat Bacillus cereus, media Luria Bertani Broth, media Luria Bertani Agar, Media Thiosulfate Citrate Bile Salts Sucrose Agar (TCBS), pasca larva L. vannamei, air laut steril dan pakan udang. Pasca larva (PL-10) Udang L. vannamei untuk sampel uji diambil dari Balai Produksi Induk Udang Unggul dan Kekerangan (BPIUUK) Karangasem, Bali.

\subsection{Metode Penelitian}

Penelitian menggunakan Rancangan AcakLengkap (RAL) dengan 4 perlakuan konsentrasi dan 3 kali ulangan.

\subsubsection{Kultur Bakteri}


Bakteri yang digunakan dalam penelitian ini adalah bakteri $V$. harveyi dan bakteri Bacillus sp. Kedua jenis bakteri ini merupakan isolat koleksi Laboratorium Perikanan Fakultas Kelautan dan Perikanan, Universitas Udayana. Bakteri $V$. harveyi dan Bacillus sp. pertama kali ditumbuhkan pada media Luria Bertani Broth dan diinkubasi menggunakan incubator shaker pada suhu $28^{\circ} \mathrm{C}$ dan kecepatan 120 rpm selama 48 jam. Stock kultur bakteri dibuat dengan menambahkan larutan gliserol $80 \%$ dan disimpan pada suhu $-80^{\circ} \mathrm{C}$ untuk selanjutnya bisa dikultur kembali. Sebelum diinfeksikan pada pasca larva Udang Vannamei, kepadatan bakteri $V$. harveyi dan Bacillus sp. terlebih dahulu dihitung menggunakan spektrofotometer pada panjang gelombang $550 \mathrm{~nm}$ dan $600 \mathrm{~nm}$.

\subsubsection{Uji Tantang Pasca Larva Udang Vannamei}

Sebelum diuji tantang dengan bakteri, pasca larva Udang Vannamei terbih dahulu diaklimatisasi dan diadaptasi selama 1 malam. Pasca larva Udang Vannamei dipelihara dalam wadah toples plastik dengan volume $500 \mathrm{~mL}$ dan salinitas $30 \mathrm{ppt}$ dengan kepadatan 25 ekor per toples. Kultur kemudian diletakkan pada waterbath untuk menjaga suhu air kultur pada saat penelitian.

Pada penelitian ini diuji 4 jenis perlakuan. Perlakuan A tidak diberikan perlakuan penambahan bakteri (perlakuan kontrol), perlakuan B diberikan perlakuan berupa penambahan bakteri Vibrio harveyi $10^{6} \mathrm{CFU} / \mathrm{ml}$ sebanyak $5 \mathrm{ml}$ (Kadriah, 2012), perlakuan C diberikan perlakuan berupa penambahan $5 \mathrm{ml}$ bakteri Bacillus sp.105 CFU/ml (Pande et al., 2015) dan perlakuan $\mathrm{D}$ diberi perlakuan berupa penambahan bakteri $5 \mathrm{ml} V$. harveyi $10^{6} \mathrm{CFU} / \mathrm{ml}$ dan $5 \mathrm{ml}$ bakteri Bacillus sp. $10^{5} \mathrm{CFU} / \mathrm{ml}$. Selama uji tantang berlangsung pasca larva udang diberikan pakan komersil dengan dosis 1 ppm sebanyak 5 kali dalam sehari (Bakhtiar, 2004).

Uji tantang dihentikan saat kelulushidupan perlakuan penambahan bakteri V.harveyi (perlakuan B) mencapai 50\%. Parameter kualitas air yang diamati selama penelitian meliputi suhu, $\mathrm{pH}$ dan salinitas. Pada akhir penelitian kelimpahan koloni bakteri tubuh pasca larva Udang Vannamei dan air kultur dihitung dengan menumbuhkannya pada media TCBS dan Luria Bertani Agar.

\subsection{Analisis Data}

Kelangsungan hidup pasca larva udang dihitung pada akhir penelitian menggunakan rumus Effendie (1997) :

$\mathrm{SR}=\frac{\mathrm{Nt}}{\mathrm{No}} \times 100 \%$

dimana SR adalah survival rate / tingkat kelangsungan hidup) dalam persen (\%)

; Nt adalah jumlah benur yang hidup pada akhir penelitian (ekor) ;No adalah jumlah benur pada awal penelitian (ekor).

Data hasil pengukuran kelulushidupan pasca larva Udang Vannamei dinyatakan dalam nilai rata-rata \pm StandarDeviasi. Perbedaan survival rate pasca larva Udang Vannamei diuji secara statistik menggunakan analisis varian satu faktor (One way anova) dan dilanjutkan dengan Uji Tukey (Uji Beda Nyata Jujur) menggunakan software SPSS versi 16.

\section{Hasil dan Pembahasan}

\subsection{Kelulushidupan Pasca Larva Udang Vannamei}

Kelulushidupan adalah salah satu parameter yang digunakan dalam uji tantang untuk mengetahui tingkat kerentanan suatu organisme terhadap virulensi patogen yang diujikan. Pada penelitian ini, kelulushidupan sebesar $50 \%$ dalam perlakuan uji tantang dengan penambahan $V$. harveyi diperoleh pada hari ke-6 periode kultur, sehingga uji tantang dihentikan pada hari ke-6 tersebut. Persentase tingkat kelulushidupan Udang Vannamei pada hari ke-6 tersebut dapat dilihat pada Gambar 1.

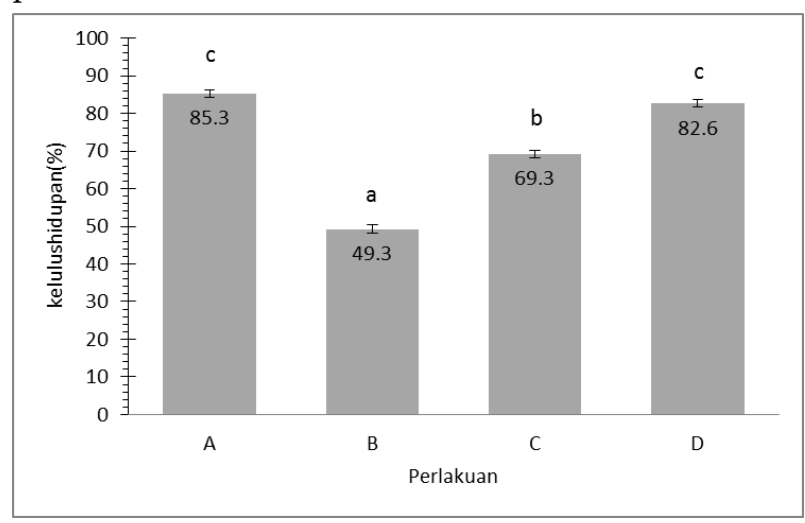

Gambar 1. Persentase Kelulushidupan Pasca Larva Udang Vannamei selama 6 hari periode kultur. Perlakuan A (tanpa penambahan bakteri); Perlakuan B (penambahan bakteri $5 \mathrm{ml}$ Vibrio harveyi $10^{6}$ 
$\mathrm{CFU} / \mathrm{ml}$ ); Perlakuan C (penambahan $5 \mathrm{ml}$ bakteri Bacillus sp. $10^{5}$ CFU/ml) dan Perlakuan D (penambahan bakteri $5 \mathrm{ml} \mathrm{V}$. harveyi $10^{6} \mathrm{CFU} / \mathrm{ml}$ dan $5 \mathrm{ml}$ bakteri Bacillus sp. $\left.10^{5} \mathrm{CFU} / \mathrm{ml}\right)$.

Berdasarkan hasil penelitian persentase kelulushidupan tertinggi pada perlakuan A yaitu perlakuan kontrol dengan persentase kelulushidupan $(85,30 \pm 4,6) \%$ dan kelulushidupan terendah terdapat pada perlakuan B yaitu perlakuan penambahan bakteri $V$. harveyi $(49,3 \pm$ $4,6) \%$. Berdasarkan hasil uji secara statistik dengan One Way ANOVA hasil persentase kelulushidupan pada masing-masing perlakuan berbeda secara signifikan $(p<0,05)$. Rata-rata kelulushidupan tertinggi terdapat pada perlakuan A atau perlakuan kontrol yaitu sebesar $85,3 \%$. Hal ini diduga karena pada perlakuan A tidak ada penambahan bakteri sehingga pasca larva udang tidak stress akibat perubahan kualitas air. Menurut Wedemeyer (1996), respon stress pada udang dapat menurunkan pertumbuhan dan selanjutnya kematian.

Kelulushidupan pada perlakuan A dan D tergolong tinggi, pada perlakuan $\mathrm{C}$ tergolong sedang dan pada perlakuan B tergolong rendah. Menurut Widigdo (2013) bahwa survival rate dikategorikan tinggi apabila nilai SR $>70 \%$, kategori sedang untuk SR $50-60 \%$, dan pada kategori rendah nilai $\mathrm{SR}<50 \%$. Rata-rata kelulushidupan tertinggi terdapat pada perlakuan A atau perlakuan kontrol yaitu sebesar $85,3 \%$. Hal ini diduga karena pada perlakuan A tidak ada penambahan bakteri sehingga pasca larva udang tidak stress akibat perubahan kualitas air. Menurut Wedemeyer (1996), respon stress pada udang dapat menurunkan pertumbuhan dan selanjutnya kematian.

Rata-rata kelulushidupan tertinggi kedua terdapat pada perlakuan D yaitu sebesar $82,6 \%$. Tingginya rata-rata kelulushidupan pada perlakuan D diduga karena adanya penambahan bakteri Bacillus sp yang berperan sebagai Anti Quorum Sensing. Anzhou et al (2013) menyatakan bahwa produksi AHL-laktonase oleh Bacillus sp. merupakan salah satu bentuk strategi bertahan hidup dalam lingkungan stress karena fluktuasi kondisi fisik dan ketersedian nutrisi yang terbatas. Berdasarkan penelitian yang dilakukan oleh ZiaeiNejad et al. (2006) menunjukkan bahwa Bacillus sp. yang diaplikasikan lewat media pemeliharaan dapat meningkatkan pertumbuhan dan tingkat kelangsungan hidup udang putih india
(Fenneropenaeus indicus). Hasil uji statistik menunjukkan bahwa perlakuan D dan B memiliki perbedaan yang signifikan. Hal ini diduga karena pada perlakuan D bakteri Bacillus sp. menghasilkan zat antimikroba yaitu bakteriosin sehingga mampu meningkatkan sintasan hidup pasca larva Udang Vannamei. Bakteriosin adalah zat antimikroba polipeptida atau protein yang diproduksi oleh mikroorganisme yang bersifat bakterisida. Menurut Compant et al., (2005) Bakteriosin membunuh sel targetnya dengan menyisip pada membran target dan mengakibatkan fungsi membran sel menjadi tidak stabil sehingga menyebabkan sel lisis. Pada perlakuan C didapatkan nilai rata-rata kelulushidupan sebesar 69,3\%.

Dari hasil uji statistik perlakuan $C$ dan perlakuan $\mathrm{D}$ memiliki perbedaan yang cukup signifikan. Hal ini diduga karena pada perlakuan $C$ tidak ada penambahan bakteri patogen $V$. harveyi. Sehingga bakteriosin yang dihasilkan oleh Bacillus sp. mempengaruhi sintasan hidup pasca larva Udang Vannamei tetapi tidak mencapai 50\%.

Rendahnya kelulushidupan pada perlakuan B diduga karena adanya penambahan bakteri $V$. harveyi yang menyebabkan terjadinya mekanisme quorum sensing. Donabedian (2003) mengemukakan quorum sensing pada patogen meningkatkan kesempatan untuk menginfeksi inang dengan menunda produksi faktor virulensinya sampai kepadatan populasinya cukup besar untuk mempengaruhi sistem imun inang.

\subsection{Kelimpahan Bakteri V. harveyi dan Bacillus sp. pada Tubuh Pasca Larva Udang Vannamei}

Penghitungan kelimpahan bakteri ini bertujuan untuk mengetahui persistensi bakteri dalam tubuh udang dan air kultur. Pada penelitian ini perhitungan total bakteri pada tubuh pasca larva Udang Vannamei dilakukan pada akhir penelitian dan hanya dilakukan pada perlakuan B (penambahan $V$. harveyi) dan perlakuan C (penambahan bakteri Bacillus sp.) Sedangkan pada perlakuan $\mathrm{D}$ tidak dilakukan penghitungan kelimpahan karena bakteri yang ada pada perlakuan D susah dibedakan pada media. Bakteri $V$. harveyi ditumbuhkan pada media TCBS sedangkan bakteri Bacillus sp. ditumbuhkan pada media LB Agar. Hasil kelimpahan bakteri $V$. harveyi 
dan Bacillus sp. yang terdapat pada tubuh pasca larva Udang Vannamei dapat dilihat pada Tabel 2.

Jumlah bakteri $V$. harveyi pada perlakuan B yaitu $16 \times 10^{5} \mathrm{CFU} / \mathrm{ml}$ Sedangkan jumlah bakteri Bacillus sp. yang didapatkan pada perlakuan C yaitu $25 \times 10^{4} \mathrm{CFU} / \mathrm{ml}$ Kelimpahan bakteri V.harveyi yang terdapat pada tubuh pasca larva Udang Vannamei dan air kultur sudah membahayakan kehidupan pasca larva Udang Vannamei. Menurut Rosa (1993) keberadaan bakteri Vibrio tidak terlalu berbahaya akan tetapi menjadi masalah jika kepadatannya dalam media pemeliharaan $\geq 10^{4} \mathrm{CFU} / \mathrm{ml}$.

Tabel 1.

Total kelimpahan bakteri Vibrio harveyi dan Bacillus sp. pada tubuh pasca larva Udang Vannamei

\begin{tabular}{cccc}
\hline Perlakuan & Pengulangan & $\begin{array}{c}\text { Kelimpahan } \\
\text { Bakteri } \\
(\mathrm{CFU} / \mathrm{ml})\end{array}$ & $\begin{array}{c}\text { Rata-Rata } \\
(\mathrm{CFU} / \mathrm{ml})\end{array}$ \\
\hline \multirow{2}{*}{ B } & B1 & $16 \times 10^{5}$ & \\
& B2 & $12 \times 10^{5}$ & $16 \times 10^{5}$ \\
\hline & B3 & $21 \times 10^{5}$ & \\
C & C1 & $37 \times 10^{4}$ & \\
& C2 & $18 \times 10^{4}$ & $25 \times 10^{4}$ \\
\hline
\end{tabular}

Pada perlakuan $\mathrm{C}$ didapatkan nilai rata-rata kelimpahan bakteri Bacillus sp. $25 \times 10^{4} \mathrm{CFU} / \mathrm{ml}$. Hal ini menunjukkan bahwa Bacillus sp. masih persisten di tubuh larva udang selama periode penelitian berlangsung. Kepadatan Bacillus sp. yang lebih kecil dibandingkan dengan konsentrasi Bacillus sp. yang ditambahkan pada air kultur di awal periode kultur sangat mungkin terjadi karena adanya pengaruh faktor intrinsik dari tubuh pasca larva udang tesebut. Perbedaan ukuran tubuh dan kondisi imun pasca larva udang vannamei diduga memiliki pengaruh terhadap kelimpahan Bacillus sp. yang hidup pada tubuh udang tersebut.

3.3 Kelimpahan Bakteri Vibrio harveyi dan Bacillus sp. Pada Air Kultur

Tabel 2. Kelimpahan bakteriVibrio harveyi dan Bacillus sp. pada air kultur

\begin{tabular}{cccc}
\hline Perlakuan & Pengulangan & $\begin{array}{c}\text { Kelimpahan } \\
\text { Bakteri } \\
(\mathrm{CFU} / \mathrm{ml})\end{array}$ & $\begin{array}{c}\text { Rata-Rata } \\
(\mathrm{CFU} / \mathrm{ml})\end{array}$ \\
\hline \multirow{2}{*}{ B } & B1 & $30 \times 10^{4}$ & \\
& B2 & $25 \times 10^{4}$ & $25 \times 10^{4}$ \\
\hline \multirow{2}{*}{ C } & B3 & $19 \times 10^{4}$ & \\
& C1 & $35 \times 10^{3}$ & \\
& C2 & $18 \times 10^{3}$ & $23 \times 10^{3}$ \\
\hline
\end{tabular}

Kelimpahan bakteri $V$. harveyi pada perlakuan B sebesar $25 \times 10^{4} \mathrm{CFU} / \mathrm{ml}$. Sedangkan kelimpahan bakteri Bacillus sp. yang didapatkan pada perlakuan C yaitu $23 \times 10^{3} \mathrm{CFU} / \mathrm{ml}$ (Tabel 4). Hal ini menunjukkan bakteri yang ditambahkan ke dalam air kultur pada awal periode kultur masih tetap persisten dalam media kultur selama proses penelitian.

Berdasarkan hasil perhitungan terjadi penurunan kelimpahan bakteri pada perlakuan B dan $C$ dibandingkan dengan penambahan di awal periode kultur. Hal ini diduga dapat terjadi karena kedua bakteri berada dalam fase penurunan pertumbuhan. Penurunan pertumbuhan bakteri bisa disebabkan oleh beberapa faktor seperti kurang optimalnya nilai $\mathrm{pH}$. Diketahui bahwa nilai $\mathrm{pH}$ optimal untuk pertumbuhan $V$. harveyi adalah 7,8-8,0 (Bonang dan Koeswardono, 1982) sedangkan $\mathrm{pH}$ optimal untuk pertumbuhan Bacillus sp. yaitu 7-8 (Combet et al., 1995). pH mempengaruhi aktivitas enzim bakteri. Suriani et al., (2013) menyatakan bahwa pengaruh pH terhadap pertumbuhan bakteri ini berkaitan dengan aktivitas enzim. Enzim ini dibutuhkan oleh beberapa bakteri untuk mengkatalis reaksireaksi yang berhubungan dengan pertumbuhan bakteri. Apabila $\mathrm{pH}$ dalam suatu medium atau lingkungan tidak optimal maka akan mengganggu kerja enzim-enzim tersebut dan akhirnya mengganggu pertumbuhan bakteri itu sendiri.

\subsection{Parameter Kualitas Air}

Parameter kualitas air yang diamati selama penelitian meliputi suhu, $\mathrm{pH}$ dan salinitas. Pengukuran parameter kualitas air dilakukan hanya pada awal dan akhir percobaan. Hasil pengukuran kualitas air dapat dilihat pada Tabel 5

Tabel 3. Rata-rata nilai parameter kualitas air

\begin{tabular}{cccc}
\hline Perlakuan & Suhu & $\mathrm{pH}$ & Salinitas \\
\hline A & $27,8^{\circ} \mathrm{C}$ & 6,9 & $35,8 \mathrm{ppt}$ \\
B & $28,3^{\circ} \mathrm{C}$ & 6,8 & $36,5 \mathrm{ppt}$ \\
$\mathrm{C}$ & $28,1^{\circ} \mathrm{C}$ & 7,0 & $36,1 \mathrm{ppt}$ \\
D & $28,1^{\circ} \mathrm{C}$ & 7,0 & $36,0 \mathrm{ppt}$ \\
\hline
\end{tabular}

Suhu terendah terdapat pada perlakuan A (kontrol) yaitu $27,8^{\circ} \mathrm{C}$ sedangkan suhu tertinggi terdapat pada perlakuan B yaitu $28,3^{\circ} \mathrm{C}$. Pada perlakuan $\mathrm{C}$ dan $\mathrm{D}$ didapatkan nilai suhu $28,1^{\circ} \mathrm{C}$. Kisaran suhu rata-rata pada air perlakuan adalah 
$27,8^{\circ} \mathrm{C}-28,3^{\circ} \mathrm{C}$. Nilai kisaran suhu tersebut masih sesuai untuk kehidupan Udang Vannamei. Hal tersebut didukung oleh pernyataan Wyban et al., (1991) yang menyatakan bahwa temperatur yang cocok bagi pertumbuhan Udang Vannamei adalah 23-30 ${ }^{\circ} \mathrm{C}$.

Berdasarkan hasil pengamatan didapatkan nilai $\mathrm{pH}$ terendah pada perlakuan $\mathrm{B}$ yaitu 6,8 dan $\mathrm{pH}$ tertinggi terdapat pada perlakuan $\mathrm{C}$ dan $\mathrm{D}$ yaitu 7. Pada perlakuan A didapatkan nilai pH 6,9. Kisaran $\mathrm{pH}$ yang didapat masih sesuai untuk kehidupan pasca larva Udang Vannamei. Menurut Haliman dan Adijaya (2004) pH optimum untuk kehidupan Udang Vannamei adalah 6-8.

Kisaran nilai salinitas yang didapatkan saat penelitian adalah 35,8-36,5 ppt. Salinitas terendah didapatkan pada perlakuan A yaitu 35,8 ppt dan salinitas tertinggi didapatkan pada perlakuan B yaitu 36,5 ppt. Sedangkan pada perlakuan $C$ serta perlakuan D didapatkan nilai salinitas 36,1 ppt dan 36 ppt. Menurut Hendrajat (2007), Udang Vannamei mempunyai kemampuan beradaptasi terhadap salinitas yang luas dengan kisaran salinitas 15 sampai 50 ppt. Namun, nilai kisaran salinitas yang didapatkan tidak sesuai dengan nilai optimum pada budidaya Udang Vannamei yaitu 15-20 ppt (Anna, 2010). Tetapi nilai tersebut tidak berpengaruh terhadap kelulushidupan pasca larva Udang Vannamei selama adanya manajemen kualitas air (Wulandari dkk., 2005).

\section{Simpulan}

Kesimpulan dari penelitian ini yaitu penambahan bakteri Bacillus sp. berpengaruh signifikan meningkatkan kelulushidupan pasca larva Udang Vannamei yang terinfeksi vibriosis.

\section{Ucapan terimakasih}

Penulis mengucapkan terimakasih kepada UPT Laboratorium Biosains dan Teknologi, Universitas Udayana yang telah mengizinkan saya melakukan penelitian disana. Terimakasih kepada dosen pembimbing yang telah membimbing penulis selama ini.

\section{Daftar Pustaka}

Anna, S. (2010). Udang Vanname. Yogyakarta, Indonesia: Kanisius.

Anzhou, M., Di, L., Xuliang, Z., \& Guoqiang, Z. (2013). Quorum quenching in culturable phyllosphere bacteria from tobacco. Int. J. Mol. Sci., 14, 1460714619.

Bakhtiar. (2004). Efektifitas Penggunaan Antibiotik untuk Mengontrol Penyakit Bakteri Vibrio harveyi pada Pasca Larva Udang Windu Penaeus monodon Fabricius. Tesis. Makassar, Indonesia: Program Pascasarjana. Universitas Hasanuddin.

Bonang, G., Koeswardono, E. S., (1982), Mikrobiologi Kedokteran Untuk Laboratorium dan Klinik Edisi 1. Jakarta, Indonesia: Gramedia..

Compant, S., Duffy, B., Nowak, J., Clement, C. \& Barka, E., A. (2005). Mini review: Use Of Plant Growth Promoting Rhizobacteria for Biocontrol Of Plant Diseases: Principles, Mechanism of Action and Future Prospect. Appl. Environ. Microbiol., 71, 49514959.

Donabedian, H. 2003. Quorum sensing and its relevance to infectiousdiseases. J. Infect, 46, 207-214.

Dong, Y. H., Gusti, A. R, Zhang, Q., Xu, J. L, \& Zhang, L. H. (2002). Identification of Quorum Quenching NAcyl - Homoserine Lactone from Bacillus species. Appl Environ Microbiol, 64, 1754-1759.

Effendie, M. I. (1997). Biologi Perikanan. Yogyakarta, Indonesia: Yayasan Pustaka Nusatama.

Fuqua, C., \& Greenberg, E P. (2002). Listening in on Bacteria: Acyl-Homoserine Lactone Signalling. Nat. Rev. Mol. Cell. Biol., 3, 685-695.

Haliman, R. W \& Adijaya, D.S. (2004). Udang Vannamei. Jakarta, Indonesia: Penebar Swadaya.

Hendrajat., \& Erfan, A. (2007). Budidaya Udang Vaname (Litopenaeus vaname) Pola Tradisioanal Plus di Kabupaten Maros, Sulawesi Selatan. Media Akuakultur, 2(2), 1-4.

Henke, J.M., \& Bassler, B.L. (2004). Bacterial Social Engagements. TREND. Cell. Biol. 16, 649-56.

Holt, J.G., \& N.R Krieg. (1984). Bergeys's Manual of Systemic Bacteriolgy Vol.1. UK: The Williams and Wilkins Co. Baltimore.

Kadriah, L A. K. (2012). Analisis Keragaman Morfologi, Fisiologi dan Genetik serta Uji patogenitas isolatisolat Vibrio sp. Tesis. Bogor, Indonesia: Sekolah Pascasarjana Institut Pertanian Bogor.

Le Groumellec, M., C. Goarant, P. Haffner, F. Berthe, R. Costa, \& I. Mermoud. (1996). Syndrome 93 in New Caledonia: Investigation of The Bacterial Hypothesis by Experimental Infections, with Reference to Stress-Induced Mortality. SICCPPS book of abstracts, SEAFDEC, Iloilo City, Philippines. p. 46.

Maryani, D., \& Dana, S. (2002). Peranan Ekstrak Kelopak dan Buah Mangrove Sonneratia caseolaris (L) terhadap Infeksi Bakteri Vibrio Harveyi pada Udang Windu (Penaeus monodon Fab.). Jurnal Akuakultur Indonesia. 1(3), 129-138.

Molina, L., Constantinescu, F., Michel, L., Reimmann, C., Duffy, B., and Defago, G. (2003). Degradation of Pathogen Quorum-Sensing Molecules by Soil Bacteriaa Preventive and Curative Biological Control Mechanism. FEMS Microbiol. Ecol., 45, 71-81. 
Nakayama, T., Nomura, N., \& Matsumura, M. 2005. Analysis of the relationship between luminescence and toxicity of Vibrio carchariae pathogenic to shrimp. Fisheries science, 71, 1236-1242.

Pande, G. S. J., Natrah, F. M. I, Ace, V. B. F, Uday, K., Yufeng, N., Peter, B., \& Defroidt, T. (2015). Isolation of AHL-degrading Bacteria From Micro-algal Cultures and Their Impact on Algal Growth and on Virulence of Vibrio campbellii to Prawn Larvae. Appl Microbiol Biotechnol, 99(24), 10805-10813.

Rosa, D. (1993). Pengendalian Populasi Bakteri Harveyi pada udang windu Hal 89-92. Dalam K. Sugama., T. Ahmad., Haryanti., \& P. Sajana (eds). Prosiding Puslitbankan No. 18. Pusat Penelitian dan Pengembangan Perikanan, Jakarta.

Suriani, S., Soemarno., \& Soeharjono. (2013). Pengaruh Suhu dan $\mathrm{Ph}$ terhadap Laju pertumbuhan Lima Isolat Bakteri Anggota Genus Pseudomonas yang diisolasi dari Ekosistem Sungai Tercemar Deterjen di sekitar Kampus Universitas Brawijaya. J-PAL, 3, 2.

Thompson, K. D. \& A. Adams. (2004). Current Trends in Immunoyherapy and Vaccine Development for Bacterial Diseases of Fish. Molecular Aspect of Fish and Marne Biology. World Scientific, 3,313-362
Wedemeyer. (1996). Growth and Ecology of Fish Populations. London, UK: Academic Press.

Widigdo, B. (2013). Bertambak Udang Dengan Teknologi Biocrete. Kompas Media Nusantara. Jakarta, 1-75.

Wulandari, T., Ninik, W., \& Pujiono, W. P. (2015). Hubungan Pengelolaan Kualitas Air dengan Kandungan Bahan Organik, $\mathrm{NO}_{2}$ dan $\mathrm{NH}_{3}$ pada Budidaya Udang Vaname (Litopenaeus vannamei) di Desa Keburuhan Purworejo. Skripsi. Semarang, Indonesia: Program Studi Manajemen Sumberdaya Perairan Fakultas Perikanan dan Ilmu Kelautan. Universitas Diponogoro.

Wyban, A. (1991). Intensive Shrimp Production Technology. Honolulu, USA: The Oceanic Institue Makapuu Point Honolulu.

Y. Combet B, K. K. Kalamba., \& P. Y. Kergoat. (1995). Effect of $\mathrm{pH}$ on Bacillus thermoamylovorans Growth and Glucose Fermentation. Applied and Enviromental Microbiology, 61, 2.

Ziaei-Nejad S., M. H. Rezaei, G. A. Takami, D. L. Lovett, A.R. Mirvaghefi, \& M. Shakouri. (2006). The effect of Bacillus spp. bacteria used as probiotics on digestive enzyme activity, survival and growth in the Indian white shrimp Fenneropenaeus indicus. Aquaculture, 252, 516-524. 